\title{
A Poesia que a Água Sonha
}

\author{
The Poetry that Water Dreams
}

\section{Roberto Lima ${ }^{1}$}

${ }^{1}$ Departamento de Ciências Sociais da Universidade Federal de Sergipe, São Cristóvão, SE, Brasil 


\section{Resumo}

$\mathrm{O}$ artigo busca como re(a)presentar alguns sentidos do sertão pela via de uma série de narrativas recolhidas em pesquisas de campo realizadas em diversas comunidades pelas beiras do rio São Francisco. O exercício metodológico está centrado na pergunta elaborada por Viveiros de Castro (2002): como levar a sério o que nos dizem nossos interlocutores? Para isso, parece-me importante, para começar, tratar esses textos ribeirinhos como fragmentos de narrativas míticas em busca de uma lógica e procurar apreender a sua função mítica em suas maneiras de representar um mundo com conflitos e de resolver na narrativa esses conflitos.

Palavras-chave: Rio São Francisco, narrativas, perspectivas

\section{Abstract}

The article seeks to represent some senses the sertão by way of a series of narratives collected in fieldworks at various communities through the margins of the São Francisco River. The methodological exercise focuses on the question developed by Viveiros de Castro (2002), how take seriously what our interlocutors say? For this, it seems important to begin with, treat these riverine texts as mythical narrative fragments seekink for a logic and seek to grasp the mythical function of these, in their ways of representing a world of conflicts and resolve these conflicts in the narrative.

Keywords: San Francisco River. Narratives. Perspectives. 


\section{Introdução}

"O rio é de um encantamento tamanho..." (Ditado ribeirinho)

"Tudo é água" (Tales de Mileto)

$A_{\text {do sertão, não por meio das famosas narrativas da construção da }}$ nação, mas pela via de uma série de narrativas recolhidas em pesquisa de campo realizadas em diversas comunidades pelas beiras do rio São Francisco.

A pesquisa de campo na qual foram recolhidas as narrativas foi realizada em várias viagens entre 1999 e 2001 para a elaboração de minha tese de doutorado (LIMA, 2002). Em linguagem desencantada, sobre o rio São Francisco, o texto refere-se a seu curso principal. Que nasce na serra da Canastra, percorre Minas Gerais, Bahia, Pernambuco, Sergipe, Alagoas e deságua 2.814 km depois no oceano Atlântico. Observo que o rio tem significados diferentes para os ribeirinhos em distintas partes de seu leito (alto, médio, submédio e baixo) e são relações diferentes que se estabelecem com o rio nessas diferentes subdivisões do curso (a partir de características como o volume de água, a navegabilidade, a piscosidade e, desde os anos de 1950, a presença de barragens).

Apesar de estar consciente dos diversos nomes que o deram (Opará, dos Currais, Mediterrâneo Brasileiro, fator precípuo da integração nacional, do Chico, Velho Chico e etc.) que se ligam à importância que o rio tem em distintos momentos na construção do discurso da nação (emblema da nação no império, integração nacional no império 
e primeira república, integração regional após a criação da comissão de bacia), não vou me ater aos discursos nacionais, exceto quando for interessante ao que está sendo discutido aqui ${ }^{1}$.

O exercício metodológico está centrado na pergunta elaborada por Viveiros de Castro (2002): como levar a sério o que nos dizem nossos interlocutores? Para isso, parece-me importante, para começar, tratar esses textos ribeirinhos, não como contos, fábulas ou anedotas, mas como fragmentos de narrativas míticas em busca de uma lógica, no sentido sugerido por Lévi-Strauss, e procurar apreender a sua função mítica, em suas maneiras de representar um mundo com conflitos e de resolver na narrativa esses conflitos.

Tal ideia é por si só bastante herética e cheia de problemas. Um primeiro problema é que se tratam, muitas vezes, de populações negras, que podem ser agrupadas dentro da categoria maior de camponeses. Aos camponeses no Brasil sempre foi negado o status de produtores de ontologias e cosmologias. Como uma vez argumentou Brandão (1993), o que quer que um índio fale vira mito na mão dos antropólogos, enquanto a mais bela narrativa camponesa é, no máximo, lenda. Se agregarmos a isso o fato de muitos dos narradores serem negros, surge por debaixo de uma boa parte da discussão do caráter mítico dos mitos (ou por poros, orifícios e trocas que não foram tratados LéviStrauss, mas que poderiam ser parte de seus estudos) os também fatos da invasão, da conquista, das alianças negro-indígenas. Essas questões exigem uma outra pergunta: esses mitos não têm cor?

Vou deixar claro, desde o início que não tenho como demonstrar a solução para o problema do caminho tomado pelas interconexões (que, para iniciar, implicaria um conhecimento das rotas de tráfico negreiro, de onde foram sequestrados os antepassados desses ribeirinhos, como chegaram ao médio São Francisco e com que povos indígenas entraram em contato para poder precisar minimamente de quais cosmologias estamos falando de tal maneira que acabo tendo de apegar-me a coisas muito simples, como se verá adiante), embora eu esteja certo de que a resposta seja sim, eles têm cor.

Lévi-Strauss (1992, p. 228) tratou disso rapidamente nos capítulos finais de História de lince, mas discutindo apenas "el gustillo de folclor europeo" de alguns mitos e a absorção como elementos nos mitos 
canadenses de personagens do folclore europeu através do contato entre viajantes e nativos. Sem dúvida a assimetria contida no título de um desses capítulos ("mitos índios, cuentos franceses") faz ressoar a crítica às vezes apressada de que nestes termos os ameríndios estavam adorando aos europeus de modo que o que é conto nesses é elevado de status àqueles ${ }^{2}$, mas Lévi-Strauss prefere tomar uma senda mais difícil, a da difusão entre a costa noroeste das Américas e nordeste da Ásia (buscando versões claramente anteriores à invasão europeia nas Américas e versões indianas ou gregas) que tomar o fácil atalho do empréstimo3.

De alguma maneira, os encontros que se deram no sertão sãofranciscano operaram de maneira próxima à dialética retratada por Lévi-Strauss para o pensamento ameríndio, com sua clássica formulação de "abertura para o outro", e não, na maneira antinômica, racista e estatutária presente na ideologia ocidental ${ }^{4}$. Espero que com o que virá a seguir eu consiga explicar minimamente o que quero dizer. Para citar o maior mitógrafo da região estudada, "[...] conto ao senhor é o que eu sei e o senhor não sabe; mas principal quero contar é o que não sei se sei, e que pode ser que o senhor saiba [...]" e, assim, quem sabe “[...] o senhor consinta, isso é sertão" (ROSA, 1994, p. 149).

\section{Encontros, Tensões e Conflitos nas Narrativas}

Talvez devesse começar concordando com Viveiros de Castro (2002), no encontro antropólogo/nativo, o único animista é o antropólogo. Aqui estou procurando fragmentos para uma visão de mundo e uma epistemologia ribeirinha. E a maneira de pensar isso é sendo atravessado pelo que eles falam do mundo, no caso do rio. Não uso essas narrativas como anedotas - como bem pontua Robert Slenes (2008) - mas como fragmentos de um saber que pode ser sistematizado. No caso aqui discutido, estou tratando do que parece ser a convivência com diferentes perspectivas representativas de várias humanidades e suas frações, mas essas mesmas perspectivas estão elas diferentemente situadas em seus pontos axiomáticos. Falando de outro modo, os ribeirinhos dessas cidades (Pirapora-MG, Xique-Xique-BA, Januária-MG, Juazeiro-BA, Petrolina-PE, Poço Redondo-SE), seja como sobreviventes do genocídio 
indígena ou herdeiros das diásporas negras e mesmo de partícipes das invasões europeias, pensam o rio como um ser vivo dotado de vontade e de razão, eles veem também seus habitantes como várias humanidades que se encontram e se enfrentam a partir de suas próprias referências e perspectivas. Contudo essas perspectivas às vezes são explicitadas a partir de temas indígenas, de temas africanos do centro ou da Mina e, ainda, europeus. Todas as narrativas são franciscanas aqui apresentadas foram recolhidas entre 1998 e 2001, em diversas viagens de campo realizadas para a elaboração de minha tese de doutorado (LIMA, 2002). Algumas foram recolhidas em entrevistas nas colônias de pescadores e outras a bordo de barcos, mas a maioria delas se deu nas casas dos entrevistados

Naquele trabalho anterior, analisei vários aspectos da vida de populações ribeirinhas do Vale do São Francisco. Contudo, analisar é, literalmente, "cortar em pedaços". Algo que acaba por aproximá-la da autópsia, como na frase de D. H. Lawrence: "analysis presupposes a corpse", um morto, portanto. Este artigo é uma espécie de retratação, porque, como acabei de dizer, repetindo o que me foi dito em suas margens, o rio, tudo que o envolve - água animais margens gentes e barcos - é para os ribeirinhos significado como algo que estou ousando denominar "pessoa". Ente vivente dono de racionalidade e vontade, com laços sociais de diversas ordens:

Nesse rio Pardo, tempos atrás ninguém dormia naquela croa ali de frente primeiramente. Um dia ela corria água pra cima, outro dia corria pra baixo, outro dia corria certo. A turma vinha de ajoujo de canoa naquelas épocas que fazia pelo Tamboril lá, soltava lá dentro do rio Pardo quando chegava aqui [na boca do rio] ele encalhava. Mas ninguém saltava para desencalhar não. Tinha que ficar todo mundo ali dentro. Ali ele já trazia a lenha e um bocado de barro, fazia um fogãozinho ali e, ficava esperando a água encher para tirar a canoa. Às vezes ficava ali, dormia, quando acordava tava no rio. O lugar tava fundo. Mas não podia saltar para desencalhar não, senão você entrava. A terra lá era movediça. Ela ia fazendo assim [faz um gesto balançando a mão] e você ia entrando. Se você enfincasse o remo, daqui a pouco você não via mais. (Zé de Lió - Januária $)^{5}$

A agência do rio é um tema recorrente em grandes cursos de água na América Latina, e a fome que o rio tem foi um dos primeiros 
sinais que me chamaram a atenção no São Francisco, como no curioso ditado que me foi dito por um ribeirinho que olhava a margem do rio, enquanto o Corpo de Bombeiros procurava um rapaz que tinha se afogado em Januária: “o rio quer é quem não sabe nadar, pois quem sabe, já é dele". Uma fome humana e canibalmente de humanos. De humanidade e de atuar na humanidade.

Mais poético foi Guimarães Rosa, nas palavras do velho Riobaldo, o narrador homem-rio: "O São Francisco partiu minha vida em duas".

O anedotário político mexicano recente apresenta um exemplo muito bom. Ao explicar o porquê da derrota estatal em controlar as águas de seu maior rio, o Grijalva, nas inundações de Tabasco, em 2007, o presidente Felipe Calderon não titubeou em dar uma explicação astrológica para o rebelde comportamento do corpo de água: infelizmente a lua cheia em conjunção às fortes chuvas dos últimos dias fizeram que fosse necessário abrir as comportas da represa de La Peñita... Ao mesmo tempo, relatórios das agências estatais de energia publicados no periódico La Jornada mostravam que uma decisão política de manter essa e outras represas públicas sem gerar energia para ampliar o lucro das represas privatizadas era uma explicação menos exotérica ${ }^{6}$ (de todo modo, neste caso o rio estaria enojado com modelo energético Mexicano).

Outro exemplo interessante é o artigo que Gastón Gordillo escreve sobre o Pilcomayo, rio a quem foi outorgada a função de ser a fronteira entre a Argentina e o Paraguai ${ }^{7}$, sempre apontado no discurso dos colonizadores como indomável ou selvagem. Contudo há uma diferença fundamental entre esse e o São Francisco. Embora ambos tenham sua história recente marcada por grandes projetos vinculados a projetos nacionais, ou binacionais no caso do Pilcomayo, o lugar deste último rio no imaginário dos povos ribeirinhos (e também no pensamento social dos países que ele marca a fronteira) é marcado por sua recusa à domesticação, ou seja, latente no imaginário futuro, já está previamente acertado com o rio que os projetos não darão certo. É o caso dos canais construídos de um e outro lado da fronteira Paraguai-Argentina, que criaram mais problemas do que soluções ao gerarem secas e enchentes alternadas nos dois países. 
Também no norte da América do Norte as relações entre rios, gentes, gentes-peixe e outras gentes é parte importante na criação de mitos e suas narrativas relacionados aos rios. Em "A gesta de Asdiwal", Lévi-Strauss (1976) percebe que parte importante das diferenças entre as versões do mito de Asdiwal recolhidas em diferentes lugares do território Tsinshian, estão ligadas a diferenças de orientação geográfica em dois rios do noroeste da América do Norte (Nass e Skeena) e a diferenças de fluxos de peixes dela decorrentes.

O caso do São Francisco é até agora diferente de todos ${ }^{8}$. Seu lugar no imaginário local é de um "rio doador" (e também no imaginário nacional, mas para esse tem decorrências diferentes que serão tratadas a seguir). Como há relações de clientela entre os homens, há para com o rio. Sua força está além de tudo, mas é dele que vem a base de seu sustento. Contudo, ainda assim, a posição da categoria medo, central para a compreensão do fenômeno clientelista, e seu significado são diferentes, pois o coronel é forte, é corajoso, é perigoso, mas o rio é tudo isso e mais: o rio é santo. Então o medo e o respeito que se deve ter para com ele são de outra ordem ${ }^{9}$.

No segundo capítulo de "o pensamento selvagem", Levi-Strauss (1997) se pergunta se é possível imaginarmos uma lógica feita apenas de retalhos e remendos. Aparentemente esse é nosso caso. Afinal, se os rios foram os grandes pontos de encontro, os grandes rios os foram em escala maior. Trata-se de colocar a relação com o rio de forma que este último não só é mediador de uma relação social, mas a relação mesma com o rio é uma relação social.

O rio como mediador aparece em alguns lugares. Em especial, é central ao argumento do paradigmático livro de Evans-Pritchard para quem as águas e rios que cortam, encharcam, vazam e adubam o território Nuer eram mais importantes para a real prática das relações sociais que a proximidade ou distância estrutural.

No caso que estamos seguindo, temos relações de troca e identificação que criam sujeitos. Assim, o trabalhador do rio enfrentase com o rio e dialoga com ele, compreendido como outro humano. Novamente este é um tema recorrente em termos geográficos, como na melodia "ol' man river" em que o velho é o rio Mississipi. Conforme a versão de Paul Robeson: 
There's an old man called the Mississippi,

That's the old man I don't like to be.

I keeps laffin' instead of cryin'

I must keep fightin' until I'm dyin'

And Ol' man river, he just keeps rollin' along. ${ }^{10}$

Muito diferentes em espírito, as duas versões da letra da música confluem (principalmente a de Robeson) para pensar o rio como um interlocutor através do qual se cria uma identidade, que em Robeson é claramente conflitiva e desafiadora. Ainda assim, ambas as versões mostram o Mississipi Velho diferente do Velho Chico. No primeiro, ao velho é reportada a passividade ("o velho que não quero ser"), e apenas os negros que incessantemente trabalham em suas margens são insurgentes. A passividade atribuída ao Mississipi não se espelha no São Francisco, que também tem seus caprichos. ${ }^{11}$

Tudo se passa como se homens e rios se afetassem mutuamente. Quando comecei a pensar o que me traziam esses discursos, a primeira questão que vinha à mente eram as antigas, mas sempre atuais reflexões acerca da participação e da mimese. A relação afetiva em que homens e rio se encontram tanto evoca Marcel Mauss quanto Walter Benjamin:

No fundo são misturas. Misturam-se as almas nas coisas; misturam-se as coisas nas almas. Misturam-se as vidas, e é assim que as pessoas e as coisas misturadas saem cada qual de sua esfera e se misturam: o que é precisamente o contrato e a troca. (MAUSS, 1974, p. 71)

“O dom de ser semelhante, do qual dispomos, nada mais é que o fraco resíduo da violenta compulsão a que estava sujeito o homem, de tornar-se semelhante e de agir segundo a lei da semelhança". (BENJAMIN, 1985, p. 113) $)^{12}$

O ensaio sobre o dom de um faz pensar no "dom de tornar-se o outro" do outro. Se Benjamin (1985, p. 108) está diretamente interessado em compreender vastas parcelas do saber oculto, não deixa de haver semelhante preocupação na poética visão de Mauss ${ }^{13}$ de uma ontologia, das pessoas criando-se por meio das coisas nos contatos misturados que são as trocas. 
Pelo menos um autor sugeriu uma proximidade entre Mauss e Benjamin. Clifford em seu ensaio sobre o surrealismo etnográfico aponta que Benjamin havia frequentado o "Colege de Sociologie", um agrupamento eclético e de vida muito curta criado por alunos de Mauss como Bataille, Leiris e Caillois (CLIFFORD, 1998, p. 173-176).

Mas talvez, até pelo apetite desse pensamento selvagem surrealista, seja importante tentar separar minimamente os universos que se encontraram nas margens do rio São Francisco.

Afinal, trata-se de uma afetação (FAVRET-SAADA, 2005) que tem suas preferências. Esses exemplos indicam também uma atuação do rio contra as represas e ao lado dos ribeirinhos. Sem saber quem compreendeu quem, se o rio ao o poeta ou o contrário, João Cabral de Mello Neto foi feliz ao escrever "rios sem discurso":

Quando um rio corta, corta-se de vez o discurso-rio de água que ele fazia; cortado, a água se quebra em pedaços, em poços de água, em água paralítica. Em situação de poço, a água equivale a uma palavra em situação dicionária: isolada, estanque no poço dela mesma, e porque assim estanque, estancada; e mais: porque assim estancada, muda, e muda porque com nenhuma comunica, porque cortou-se a sintaxe desse rio, o fio de água por que ele discorria.

*

O curso de um rio, seu discurso-rio, chega raramente a se reatar de vez; um rio precisa de muito fio de água para refazer o fio antigo que o fez. Salvo a grandiloquência de uma cheia lhe impondo interina outra linguagem, um rio precisa de muita água em fios para que todos os poços se enfrasem: se reatando, de um para outro poço, em frases curtas, então frase e frase, até a sentença-rio do discurso único em que se tem voz a seca ele combate. (MELLO NETO, 1979, p. 23) ${ }^{14}$

Questões políticas são derivadas disso. Quando um pescador entrevistado em Pirapora diz que "o que acabou com a pesca foi o IBAMA", a literalidade da afirmação pede que se compreenda um texto mais longo subjacente, em que a piracema sempre foi a grande época de fartura para os pescadores. A decisão de negar aos pescadores o 
direito de pescar nessa época é visto como uma reserva dos peixes (uma expropriação, melhor dizendo) para pescadores e consumidores não ribeirinhos. Para um, podemos dizer assim, mercado (e uma elevação a níveis estratosféricos da "ideologia do doador infinito"). O resultado é a superexploração dos stocks de pescados e negação aos pescadores do direito de comer peixe. Assim, nas semanas santas, desde a década de 1990, o pescado consumido em cidades como Juazeiro, Petrolina, Pirapora e outras é importado de rios da Amazônia, em especial o Madeira, e os pescadores comem "moqueca de cabeça de surubim", que eles compram (!) pois os surubins que eles pescam são vendidos inteiros. ${ }^{15}$

No rio São Francisco, pode-se dizer que, embora variável quanto aos significados associados, conforme o lugar e posição política do narrador, este diálogo homem-rio é fundamental no processo pelo qual os trabalhadores do rio constroem-se enquanto sujeitos. E para que tal ocorra, o rio também precisa ter personalidade.

Para começar, tal como o pescador, o rio dorme. As águas dormem "na meia noite velha", que não é uma hora de relógio, mas um momento neutro entre dois dias: Um momento em que tudo cessa. O rio, onde é silencioso, não corre. Tal como as rodas d'água das corredeiras do afluente rio Corrente, acima da cidade de Correntina, a corredeira de Pirapora silencia: ela para "de trabalhar", e essa é outra característica humana do rio, embora não seja esmiuçada pelos pescadores nas narrativas que recolhi ${ }^{16}$ :

Você pode ver, meia-noite essa cachoeira aqui pára, fica um silêncio, 4 a 5 minutos, depois recomeça. Só quem nunca amanheceu numa beira de rio que nunca viu. (Manuel-Pirapora) ${ }^{17}$

Ou, nas palavras de Guimarães Rosa:

Há uma hora certa, no meio da noite, uma hora morta, em que a água dorme. Todas as águas dormem: no rio, na lagoa, no açude, no brejão, nos olhos d'água, nos grotões fundos. E quem ficar acordado, na barranca, a noite inteira, há de ouvir a cachoeira parar a queda e o choro, que a água foi dormir... Águas claras, barrentas, sonolentas, todas vão cochilar. Dormem gotas, caudais, seivas das plantas, fios brancos, torrentes. O orvalho sonha nas placas da 
folhagem. E adormece até a água fervida, nos copos de cabeceira dos agonizantes... (ROSA, 1997, p. 66)

É uma hora que deve ser respeitada e, embora as pessoas pesquem à noite, não se atrapalha o sono do rio. Ninguém deve ir ao rio na meia noite velha, e fica a pergunta: se todas as águas dormem, será que o sangue também para e o coração cochila...?

Num sentido inverso do ir e vir, quando o rio vai à cidade e ocorrem as grandes cheias, sempre surge o relato de um surubim pescado dentro da igreja, visita que inverte as relações entre lugares sagrados e da vida, e alteram, na visita do peixe a relação humano/ natureza nesse espaço. Também suas marcas são indeléveis: na casa de Lenine, quando o entrevistei em Januária no ano 2000, a marca da água na enchente de 1979 não saía da parede, por mais que ele a pinte por cima.

Centrais para a vida das populações ribeirinhas, os peixes têm, assim como os homens, um dia a dia de trabalho e descanso. Têm suas casas, seus coites nos troncos submersos "para onde rumam para descansar", como conta seu Binuzinho, pescador de Januária:

$O$ rio antes era estreito e fundo. E tinha muito pau: então tinha o peixe porque o peixe é que nem a gente: você acorda e vai tratar das tuas coisas, vai trabalhar. Meio dia você quer voltar para a sua casa procurar o almoço, fica ali um pouco, ai sai para trabalhar de novo. Aí de noite você volta para dormir: assim é o peixe, o pau é o coite do peixe.

Você não sai de casa cedinho pra resolver seus problemas e depois volta na hora do almoço para o seu coite para comer? Assim igual é o peixe. (seu Binu - Januária ${ }^{18}$ )

Falas semelhantes me foram ditas várias vezes para explicar o porquê de os peixes terem diminuído em número, em paralelo ao arrancamento dos paus que haviam dentro do rio pelos proprietários de lanchas que utilizavam redes de arrasto.

Aqui, a ideia de duas humanidades relacionadas conflitivamente (e predatoriamente) é bastante clara e evoca de perto a ideia de perspectivismo de Viveiros de Casto, e essa é uma base interessante para pensar várias das narrativas aqui apresentadas em que se percebe um certo horizonte de humanidade em comum e em algumas situações, intercambiável: 
[...] uma teoria cosmopolítica segundo a qual os diferentes centros de agência disseminados no universo são dotados de pontos de vista incompatíveis: a visão que os humanos têm de si mesmos e de seu ambiente é diferente da visão que os animais têm dos humanos, como a visão que os animais têm de si mesmos (e de seu ambiente) é diferente da visão que os humanos têm dos animais, e assim por diante. Para dar o exemplo canônico: os humanos se vêm como humanos e aos jaguares, como jaguares; mas os jaguares se veem a si mesmos como humanos e aos humanos como porcos selvagens - os jaguares veem o sangue de suas presas como cerveja de milho, ou alguma outra bebida apreciada por todo humano que se preza; e assim por diante. (VIVEIROS DE CASTRO, 2008, p. 93) ${ }^{19}$

Assim, também outras relações aparecem no cruzamento da ação espoliadora dos fazendeiros com a linguagem para falar dos lugares de procriação em que se vê o rio vivo e alude-se a um sangue fertilizador, pois os fazendeiros fecham os "sangradouros", saídas da água das lagoas marginais (locais de desova e berçário ictíico) para o rio: as águas pubas. É nesse sangrar que o rio se enche de peixes. ${ }^{20}$

Continuando meu percurso "animista" e mudando o sujeito descrito, quero me deter em esboçar algumas questões sobre características e caráter das "entidades aquáticas"21.

Uma característica que foi descrita há muito tempo é a mobilidade das entidades ribeirinhas brasileiras. Câmara Cascudo escreveu isso sobre a cobra grande, que um dia aparecia num rio amazônico, outro no São Francisco. Em que pese essa mobilidade, ela não se dá do mesmo jeito em um e outro rio, ou melhor, ela não explica fenômenos semelhantes da mesma maneira: no rio Tapajós o fenômeno da terra caída é explicado porque a cobra grande se mudou, muitas vezes por conta da ação humana ela, irritada com os inquilinos de acima, deixa de sustentar aquela terra e deixa que o rio a leve (Edna Alencar, comunicação pessoal); no São Francisco a terra cai porque o pescador fez algo que a irritou e ela foi por baixo da margem procurá-lo em casa. Se o pescador lograr sobreviver, deve mudar de modo de vida. Nunca mais irá pescar, pois a cobra grande não deixaria de buscá-lo em qualquer beira de rio a que chegasse. 
Se o pretexto, uma ação do ribeirinho e o resultado, o afundamento da terra, são iguais, o sentido da ação, e o caráter passivo ou ativo da entidade são diametralmente opostos.

Contudo, no Rio São Francisco, é em torno ao cumpadre d'água que mais se torna visível o processo de violento conflito da conquista e da colonização. Invariavelmente chamado nas coletâneas de folclore (e mesmo em parte da antropologia) de caboclo d'água ou nego d'água, ele é sempre reportado pelos ribeirinhos como cumpadre d'água. A mudança do nome é muito sugestiva da diferença estatutária e discriminatória racialmente informada no primeiro caso e da aliança no segundo caso. Os termos caboclo e nego, tantas vezes pejorativos são transformados em cumpadre, o aliado-parente ritual que, como uma vez discutiu Antonio Augusto Arantes (1993), recria a família sem o pecado original.

Mas o cumpadre é ainda marcado por duas humanidades que se foram postas a dialogar (e lutar) no sertão, pois existem o vermelho e o preto, e o vermelho, certamente um indígena, é reportado mais bravo, ou melhor, mais sistemático em sua forma de viver, reagindo de forma mais violenta a qualquer falha de seus compadres de terra.

Quero aqui marcar três "cacos" dessa lógica como disse LéviStrauss. Primeiro a ideia de duplicidade, que se expressa também em um ditado que diz "tudo o que tem em cima da água tem debaixo", remete imediatamente à cosmologia fundamentalmente dualista dos Yorubá em que todas as coisas são agrupadas em pares: tudo o que tem no orum ("mundo dos deuses") tem no ayie ("mundo dos homens") (WOORTMANN, 1978, p. 26, 27 e 56) em que se deve lembrar a relação do orum com a água ${ }^{22}$. Segundo, a presença indígena na cor (e talvez uma associação ao sangue) e também ao mundo dos encantados que fica abaixo dos rios (GALVÃO, 1952) 23 ; e terceiro, a presença marcada do compadrio, relação cristã (ao contrário do que se esperaria em grupos indígenas sul-americanos, em que a relação mais marcada é a entre cunhados, ou africanos, em que se esperaria um avunculado intermediando relações com ancestrais $)^{24}$.

Aliás, índice interessante dessas duas humanidades de terra e duas de água que se encontram são as oferendas que se deve dar ao 
aliado, fumo e cachaça: essa deixa-se na margem, em lugar próximo ao rio e aquele, fica seguro na mão, a mesma mão que sustém a rede, de modo que possa ser atirado ao rio a qualquer movimentação que seja percebida como "dele" (quando o pescador retorna à terra e não encontra a garrafa, também significa que o cumpadre ali passou). Uma oferenda é feita de cana de açúcar, planta do sudeste asiático e inicialmente trazida ao Brasil por negros escravizados e a outra, de planta originária das Américas e que é utilizada em oferendas propiciatórias de norte ao sul do continente (ver Lévi-Strauss, 1997, Capítulo 2).

Sobre esses seres, quero inserir um longo e dramático depoimento. Esta entrevista foi realizada na casa de Zé de Lió, em Januária, e estava presente seu compadre Binu ${ }^{25}$, que foi quem me apresentou a ele. A transcrição é fiel. Apenas para ajudar o leitor na contextualização dos vários sujeitos presentes - sejam dentro da narrativa, sejam como ouvintes -, da oralidade ao texto escrito, acrescentei algumas explicações sempre entre colchetes. Narra Zé de Lió:

Já vi. Lá na mata do engenho. Já vi coisa lá de ó, eu assombrar. Eu mais um velho de nome Zé dos Arroz, que tinha aqui: o senhor não lembra falar dum nome do Zé dos Arroz?

Aqui na mata do engenho, essa fazenda que é do Jorge da Mata. Aqui ó, está o beiradão do rio aqui e, aqui sai uma ilha que faz um outro saco, e aqui tem um pé desses de jenipapo.

E eu vim desse lado aqui [por fora, descendo o rio], cheguei, encostei. Mas deixe que até aqui a croa estava nova, estava molhada não tinha lugar para nós dormirmos. Então nos deitamos dentro da canoa.

Quando foi de noite, eu vi que a lua vinha saindo, eu disse: 'seu Zé, vamos ali embaixo mais eu', ele disse 'vamos'. Aí eu peguei um pedaço de pau assim, saí com o cacete na mão e ele me acompanhou. Me acompanhou descendo, descendo, chegou aqui assim, eu fiquei prestando atenção: do lado do pé de Jenipapo eu vi roncar uma coisa como quem fosse um porco. Eu falei: "seu Zé, o seu Jorge da Mata tem chiqueiro aqui?". Ele falou "tem". Eu achei que era porco mesmo do chiqueiro, mas eu fiquei naquela dúvida.

E foi, passou um pedacinho começou a mexer uns peixinhos lá dentro, eu disse "vamos embora [pescar]". Chamei todo mundo, cheguei, enfinquei um pau aqui [para marcar o início da rede] e vim com a rede, virei aqui, na frente, vim pelo lado de cá, vim [ao narrar ele gesticula mostrando como fez uma espécie de grande U com a rede, dando uma volta], cheguei aqui. 
Você lembra de Isaias? do cunhado dum Dias? Ele era o proeiro meu: eu tirava o piloto da canoa pra rede não vir aqui para a beirada, que eu tinha visto roncação aqui, e ele só chamando a canoa para perto do barranco e eu tirando o barco assim de lado, quando chegou aqui [perto do Jenipapeiro] eu fiz isso com o barco ó, fiz isso, a rede fez isso e eu fiz isso. Quando chegou aqui dentro eu fiz isso ó, e deixei isso [rede em forma de saco, com a boca aberta] aqui.

Aí eu falei: 'Agora seu Zé [dos Arroz], o senhor vai dentro do barquinho e os meninos vai na canoa fazer o baticum de cima para cá. Quando chegar o baticum, a gente fecha [a rede] para cá, né'. Aí ele falou: 'eu sozinho não vou. Prefiro nós ir de três, mas sozinho não vou'. 'Por que?' "Não, eu não tenho muito costume de remo, e fica sem jeito de eu remar e bater" - que a gente bate, cutuca o chão e o peixe corre pro meio da rede. Aífomos: os três. Fazer o baticum, pa-pá-pá. E aqui na proa da canoa eu acendi um candieiro. E a gente pá-pá-pá... quando primeiro chegou na posição eu fechei a rede. Depois que eu fechei aqui, compadre [Binu], aí os meninos [que estavam comigo]... um Tião está [vivo] ainda, Virição ainda, ainda tem, compadre [Binu], um bocado deles ainda está vivo, o Marinho... aí eu fechei.

Quando eu fechei, eu pego o reboque e venho aqui pra fora e aqui fora fiquei. E estamos puxando a rede: puxando puxando puxando, puxando puxando e, daqui a pouco a rede vai e engancha. A rede enganchou: 'Zé [de Lió], tá enganchada.' Aí eu saí [entra no barco e recorre toda a rede buscando o lugar onde estava presa], pegando o pano da rede e fui, praça e afora fora fora, vinha vinha vinha: 'Não achei pau não, puxa aí. 'Ta vindo' [respondem os companheiros]

Aí, tava indo, tava indo, tava indo... tornou a enganchar. Aí eu vou. Já comecei a ficar com raiva. Peguei o pano e fui vendo, vu-vu-vu-vu, arrudiei ela todinha: 'puxa esse diabo aí'. 'Tá vindo não' [responderam]. Pensei: 'a pois, isso é falta de força'. Peguei no reboque, peguei na cortiça assim e puxei: torou a corda.

'Aonde que esse trem prendeu?, pelo amor de Deus!' Volto novamente. Quando chego aqui, cumpadre [Binu], por amor divino: eu cheguei essa posição aqui [se agacha no chão para mostrar], eu estou com o joelho aqui, a pois não balançar [o barco] peguei no colo da rede e fiquei assim: apontou, tipo uma capivara, numa distância duns 8 metros, eu olhando a lua assim eu falei, eu vendo: 'aqui tem uma capivara aqui dentro. Vamos pegar ela'.

Como vamos fazer? Nós apanha a remanga e passa e passa por fora, $e$ fecha a rede. Junta um bolo de rede para a gente pegar ela. [Dá a voz de comando] "Corre a remanga". Corremos a remanga, corremos a remanga: corremos a remanga... deixa que a rede da remanga não dava para virar ela toda. Tinha que recolher mais, para apanhar mais, para poder completar. 
Naquilo que eu estou ali, compadre [Binu], que eu falei que era capivara e eu fiquei nessa posição aqui, agachado... compadre [Binu], eu quero que Jesus me cegue e não me dê mais as minhas vistas: ele apontou de cima de mim assim, de cara a cara comigo assim: de cara! De cara! Assim ó: a cabecinha dele é peladinha peladinha que não tem nada! De cara aqui ó! E Eu fiz isso ó-ó: sentei na água da canoa de medo que eu fiquei. Sentei dentro da água da canoa, seguro da corda aqui, dentro. Com roupa com tudo, assentado dentro da água e ele ali ó! E Eu fiquei tremendo, sem saber o que fazia: olhava lá para o seco, olhava para cá e entalei a boca. Quê que eu fiz: quando voltou as reações minhas, eu peguei as cortiças levantei as cortiças e rumei elas na beira da canoa. As cortiças fez 'trá!'. Ele afundou e eu ó, pro seco: 'Menino num é capivara, é cumpadre que está aí dentro'.

Conversa do Divino, cumpadre [Binu], olha: a água aqui e nós estava puxando a rede como aqui uns oito metros, e ninguém entrava dentro da água. Todo mundo correu: a água tá lá a gente está aqui puxando a rede. O que nós puxava, ele puxava também. O que nós puxava com os braços nossos, ele puxava tudinho para trás. Nós ia esticando assim, quando soltava ia que nem borracha, puxava para trás.

Pronto. Pensamos: 'vamos largar'. 'Quê que vamos fazer'. Aí nós ficamos tudo no seco, com medo! 'Vamos apanhar a rede?' 'Vamos'. Fomos: em quatro. Entramos no rio, apanhamos... fui puxando o barco, fui beirando o barco... chegamos na ponta de baixo pegamos, ai pedimos. Aí começamos a pedir, né. Pegamos uma faca, cada um pegou uma faca assim de junto ${ }^{26}$... Olha como é que tava o trem para nós: e pedimos pedimos pedimos. E fomos apanhando a rede, apanhando a rede: apanhando a rede. Logo que nós chegamos aqui ó: graças a Deus soltou tudo e aí nós catamos. Catamos.

Compadre [Binu], depois de apanhada a rede, aqui na ponta da ilha, a gente tinha que voltar tudo, e tinha que atravessar tudo para Barro Alto. Quando nós acabamos de apanhar a rede, que chegamos aqui, ele tava dando cangapé aqui na ponta de baixo da ilha: cabulou? Ei pá! Pá! Dava aquele cangapé no rio. Até nós encostou.

Quando nós encostou, quê que nós fez para poder atravessar o rio? Eu peguei as canoas e fiz isso ó: ajoujei, amarrei essa corda da proa desse aqui, amarrei aqui, fiz aqui, passei uma corda por baixo, dei um nó. Eu fiquei no piloto, [os barcos] tudo amarrado, um na voga, outros no remo. Que fizemos: viramos aqui de cabeça acima. Não atravessamos não, subimos a coroa de cabeça acima. Fomos atravessar para sair cá em cima na cabeça do Barro Alto. Aí descemos o barranco de cabeça abaixo empurrando na beira do barranco. De cabeça abaixo, de medo dele.

Num demos um lanço de rede mais nessa noite de jeito nenhum. Todo mundo apanhou as cobertas foi dormir lá no meio da croa, com medo. Mas passamos a noite sem dormir. De que, no final de tudo? Isso aconteceu comigo e ainda tem deles pescador ainda vivo que tava mais eu.

ILHA

v. 22 , n. 1, p. 41-74, junho de 2020 
[Neste ponto, inclui eu e Binu no relato:] Eu duvido nós três, dele pegar uma corda para puxar pra lá e nós puxar pra cá e a gente sustentar. Quem disser que é mentira, por essa luz divina que eu to vendo, eu quero ver minhas vistas ceguinhas, não quero enxergar mais nada na minha vida, do jeito que aconteceu comigo. De cara a cara. Sentei com a roupa dentro da água, de medo dele. Que eu nunca tinha visto essa coisa não: ele não rasgou um pedaço da rede, ele não rasgou uma malha da rede. Era só brincadeira dele. Ele sustentava, que ele lá no fundo ele pegava a rede e nós podiamos morrer de puxar.

Que existe, existe. (Zé de Lió, Januária)

Dona Jovem, com seus 90 anos, contou de seu encontro com o mesmo ser:

Tem umas coisas que não gosto nem de contar que tem gente que acha que é mentira, mas uma vez o Manuel [falecido marido] chegou lá das bandas do Urucuia, com três canoas de peixe e ele tava tão cansado que foi dormir. E eu fiquei lá ajudando a tratar o peixe. Quando terminei, eu fui deitar e ele perguntou 'já amanheceu?' eu disse 'Não, são duas horas agora, tô me deitando'. Ele perguntou 'você topa de banhar?' 'topo'. Aí, a gente era casado de novo (riu), a gente olhou na direção da praia tinha uns meninos tocando violão, ele disse 'vou pegar o revólver'. Ele pegou o dele, me deu uma lanterna e a gente arrodeou para ir para a praia sem ser visto.

Quando a gente estava tomando banho eu ouvi vozes: 'valha Manuel, será que tem alguém ouvindo gente aqui e maldando que reconheceu a minha voz, ouviu voz de homem e pensa que você está viajando?'

'Deixe de bestagem Jovem'

Mas aí eu só ouvi as braçadas: chuque, chuque e dava para ver que era alguém forte, parrudo e foi chegando perto. Ai eu vi que quando chegou perto mudou a braçada, chuque, chuque [como se nadasse em pé].

Aí o Manuel falou 'ô cumpadre, está me estranhando?'

Foi ele falar isso e aquilo começou a nadar de novo, dando a volta na gente e mergulhou e a água ficou lisinha... depois disso me deu uma tremedeira: eu não sou de esmorecer não, mas eu não vou mais nesta beira de rio lá para meia-noite. (Jovem, pescadora aposentada, 90 anos à época da entrevista, Januária)

Não quero "quebrar em pedaços" os trechos acima, mas devese salientar essa relação pessoal com o ser da água, que, muito humanamente, não gosta de ser chamado "bicho d'água" e que zela pela honra das pessoas às quais mantém laços de reciprocidade ${ }^{27} \mathrm{e}$ respeito ${ }^{28}$ :

ILHA

v. 22, n. 1, p. 41-74, junho de 2020 
Eu queria é ter jogado o facho na cara dele, para ver o rosto, que normalmente a gente não vê, mas às vezes... mas o Manuel não deixou, disse que se eu fizesse isso ele ia ser mau com a gente. (Jovem, Januária)

É um ser poderoso e como tal deve ser respeitado. Mesmo quando por distração sua, é visto nadando, não se deve incomodá-lo:

Vinha o Manuel mais dois companheiros pescando de joão bobo ${ }^{29}$, ai um peixe beliscou o anzol e a cabaça sumiu.

Aí o Manuel viu mais pra frente uma cabaça flutuando e falou 'ô fulano [indecifrável o nome do pescador] olha a tua cabaça ali!'

Aí eles foram pegar. Quando chegaram perto, que ele se abaixou, foi um cangapé [quando o peixe se bate na superfície] tão grande que virou o barco e eles tiveram que nadar para a margem. (Jovem, Januária) [o cumpadre tem a cabeça grande e lisa como uma cabaça]

A opacidade e impenetrabilidade plena em seus segredos que a água, essencial à sobrevivência, faz questão de manter ${ }^{30}$ permite que a vida sob as águas seja tema de um imaginário muito rico onde as coisas podem, inclusive, metamorfosear-se.

Desse modo, o que se compreende por vida é algo muito mais complexo. "Tudo que tem em cima da água tem embaixo" 31 : cachorro, cavalo e cumpadre: seres que são denominados genericamente de "os bichos d'água", no dizer daqueles que vivem de explorar os que vivem do rio.

Continuando esse caco, os termos "animal" ou "bicho" são utilizados para seres que fazem parte da realidade (não são compreendidos como sobrenaturais) mas, ou escapam à classificação mais clara, em sentido semelhante ao que Douglas discute em pureza e perigo ou aproximam-se ao que em tradições americanas se chama de guardiões e/ou duplos ${ }^{32}$.

Na próxima narrativa, a "paridade" e a negação do ímpar ambíguo - está mais próxima ao modelo africano que ao modelo ameríndio, onde a paridade está ligada a duplos animais no xamanismo das terras baixas da América do Sul e em Mesoamérica.

Entrevistando uma pescadora de Januária, ela disse:

Eu tinha sete anos, meu pai pescou um surubim velho, tão velho que tinha até cabelo na cabeça. Eles soltaram o peixe da rede. Que... quando pegava um peixe assim velho, que tava virando um bicho, ele soltava. 
Outra vez eles pescaram um [surubim velho] que tinha até peitinho, como menina moça [também soltaram]. (Ifigênia, cerca de 40 anos, filha de dona Petu, famosa pescadora da cidade que havia falecido há pouco, Januária) ${ }^{33}$

Mas como é possível analisar narrativas como essas, principalmente a de Zé de Lió, com sua dramática carga emocional? Zé de Lió, assim como Jovem e Tiririca, faz questão de situar muito bem as pessoas que o ouviam no espaço onde se deu o encontro, e de cercar o ocorrido com a possibilidade de verificação pela nominação dos companheiros que estavam presentes e que também podem ser questionados. Então, em primeiro lugar elas se mostram além da possibilidade de uma rápida classificação como falsas, ou como irrupção de uma "consciência falsa": Zé de Lió dá um testemunho de algo, experiência que lhe marca. Tais falas teriam então um caráter performativo, para usar o termo de Austin? Sim, no sentido de que tais enunciados estão "fazendo algo presente". No início do século XXI são vozes de um contramundo talvez, se pensarmos no fato de serem vozes contra-hegemônicas ou enunciados que não cabem dentro de um normativo projeto modernizador, como o analisado por Foucault.

Contudo, uma pergunta pode ser colocada: de quem é essa voz? Pergunta clássica de toda descrição de "experiência mística". Colocar o último termo entre colchetes é interessante por marcar a premissa básica da desconstrução, que é dizer: não será o lado "fraco" da oposição concreto/místico, aquele que realmente permite o lado "forte"? Seria o caso de perguntar até que ponto o concreto não é uma simplificação, ou se não é mais interessante esquecer tal oposição e trabalhar com um real ampliado? O compadre d'água sempre assustava, mas não era incomum vê-lo. Com narrativas de dramaticidades diversas (sem dúvida a mais poderosa que recolhi foi a do Zé de Lió), ele permeia a experiência dos pescadores da região, tanto quanto uma onça, para falar de um animal de terra que tem seu imaginário associado: ianareté, o grande comedor de gente.

Argumentei em outro lugar (LIMA, 2002) que o que era chamado de folclore elidia partes importantes da experiência destas pessoas. Iniciei esse artigo dizendo que a ideia seguia a indignação de Carlos Brandão (1993), para quem os camponeses teriam sido espoliados em 
seu imaginário pelas ciências sociais, que deram menor valor a suas narrativas e teriam supervalorizado as narrativas indígenas: Qualquer narrativa vinda de um índio era promovida a mito, enquanto a mais bela narrativa camponesa seria, no máximo, lenda. Para Brandão, tal ação redundava em um desencantamento do outro. A negação pela teoria do outro possuir sua própria opacidade, seu mistério.

Mas Zé de Lió afirma: "que existe, existe":

E porque que dizem que não tem? Porque não temos filmadora. E a gente vê isso é de noite. No Urucuia, agora é que o rio está muito poluído de barco, mas antes, quem era nós dois para dormir na beira do Urucuia: tinha de um dormir e o outro ficar acordado.

Nunca ouvi falar dele comer ninguém, mas ele assombra a pessoa, que nem ele fez com compadre Rufino, que ia pescando mais Manuel, ele pegou a canoa do cara, ele entrou por baixo da canoa suspendeu a canoa para cima, ficou ele dentro da canoa e a canoa com a frente levantada, com se tivesse um motor no toco. (Zé de Lió-Januária)

Eles falam sério, sejamos sérios. Essas experiências que vêm do rio podem trazer uma pista de uma porosidade ou justaposições entre diferentes cosmologias, de grupos não indígenas que partilham (pelo menos) parcialmente do que Eduardo Viveiros de Castro chamou de Perspectivismo amerindio, no sentido do mundo habitado por varias humanidades que podem intercambiar em certos momentos seus pontos de vista. Mas também de paridades/imparidades que aqui vieram pelo tráfico de escravos.

Ademais, parece interessante que as "passagens" ou cruzamentos parecem guardar a memória de suas diásporas e massacres como indicam as relações caboclo-nego-cumpadre.

Também é interessante pensar a dificuldade que a antropologia sempre teve de aceitar a existência/racionalidade dessas experiencias/ possibilidades. Essa tensão mostra um tema em que a literatura tem sido sempre mais capaz. No Brasil, talvez Guimarães Rosa tenha sido o autor mais feliz em fazer interagir uma paisagem como personagem aos homens que a habitam ou atravessam. É o caso da novela Recado do morro, do rio São Francisco que divide a vida de Riobaldo Tatarana em duas partes no romance Grande Sertão: Veredas, do conto a terceira margem do rio... (ROSA, 1994) ${ }^{34}$. 
No caso dos ribeirinhos, a experiência do rio entranha nesses agentes. Ao fim de uma vida que sempre dialogou com o rio, os pescadores aposentados, idosos às vezes com dificuldades de caminhar, vão todo dia ver como está o rio: "já fui lá hoje, tá maretadinho..." (Zé da Maria, 70 anos, Carinhanha).

E o mesmo ocorre com os marujos: o pai do José Falcão que morreu quando não mais o deixaram navegar.

Importante ver que as relações homens/rio não são todas do mesmo tipo, a depender de sua posição de status na vida local, a sua opção pela vida no rio pode ser fruto de um saudosismo da infância dentro da barca de seu pai, como parece ser o caso do Luiz Coelho, dono da barca Sinhá Licinha, que contou:

Quando eu era menino, viajava na barca do meu pai, aquilo era uma vida de sonho, eu ficava ouvindo aquelas histórias dos marujos, e frequentava as zonas, aquilo ficou tão marcado em mim que cresci, fui trabalhar, na hora que juntei um dinheiro, comprei uma barca. (Luiz Coelho, 56 anos, bordo da barca Sinhá Licinha)

Mas outras possibilidades são mais radicais, como na fala do Manu Guia, pescador de Pirapora:

O pescador fica arranchado nessas croas e beiras de rio, sozinho, dias e meses, vira até bicho.

Entendo que ele fala de um processo de autopercepção do isolamento social como um caminho a outra socialidade (como gente não humana?), duplo do processo que Rosa descreveu no conto $\mathrm{Meu}$ Tio Iauaretê, mas reversível, sem aquela radical expulsão do convívio social "humano" que nesse escrito de Rosa é irreversível.

Aqui tenho de me arriscar a perder totalmente o controle sobre a descrição do pensamento selvagem que estou tentando: cabe perguntar se não é esse cruzamento de sistemas que estou descrevendo o que está implícito no título do conto "meu tio o Iauareté", de Guimarães Rosa, em que o narrador mestiço (filho de mãe indígena e pai branco) é iniciado pelo tio, do qual é assassino e aprendiz, e se transforma nele-jaguar: o grande comedor de gente indígena? Rosa, no título ainda agrega a relação do tio (mas não é o tio presente nos sistemas africanos como o intermediário entre família como agrupamento de 
parentes vivos e família como linhagem de ancestrais mortos: o tio aqui é mais marcadamente totêmico ou xamânico ${ }^{35}$ ) ao jaguar (em seu nome tupi: o grande/verdadeiro comedor de gente) que não é normalmente falado no Brasil branco ${ }^{36}$. Ademais, no fim do conto o narrador tem que enfrentar a morte ${ }^{37}$ : como mestiço ou como indígena ${ }^{38}$, como feiticeiro ou como xamã. Sem contar que um autor tão alquímico como esse pode ainda estar aludindo ao fato que em muitos países da América Latina o "tio" é uma maneira indireta de referir-se ao diabo.

Se focamos na relação personagem-jaguar e se tomamos uma óptica do perspectivismo ameríndio, talvez fique bastante raro o "mestiço" virar um jaguar, ambos para o indígena e para o branco são outros humanos, com suas perspectivas intercambiáveis, o personagem claramente faz uma parte do caminho iniciatório, mas não para ser xamã, como atesta o título em que o jaguar é o tio: em determinado momento ele se transforma em jaguar e ele vê o jaguar como o jaguar se vê e aos "humanos" como os jaguar os vê, mas ele não se torna o diplomata cosmopolítico, a passagem de caçador a amante o prende do lado da jaguar Maria-maria, de quem vira companheiro. Não é à toa que um homem da cidade, uma visita, presumivelmente branco, absolutamente alheio aos encontros que se dão no sertão, o mata ou tenta matá-lo. ${ }^{39}$

Para o caso dos narradores ribeirinhos negros que aqui retomo, podemos talvez indicar uma transformação ou possível redução do xamanismo? Teríamos neste caso pescador como, se não um diplomata cosmopolítico (VIVEIROS DE CASTRO, 2008, p. 96 e 97), pelo menos como alguém que atravessa essas fronteiras?

Essa questão, do que são os "animais" é bastante espalhada no centro-oeste brasileiro. E muitas vezes pode ser referida na distinção feita entre caça versus animal ou bicho. Remeto ao que me contou Andrea Borghi: em um curso para guarda-parque feito no Parque Nacional Grande Sertão: Veredas, os "facilitadores" de uma ONG brasiliense chamada Funatura sempre chamavam a atenção e corrigiam as falas dos futuros guardas-parque na região do PNGS:V: "ai, quando apareceu a caça..." "caça, não, fulano, animal tal (tenho lembrança de que era um veado mas não posso afirmar)". O discurso ecológico não 
vê as distinções aqui tratadas, ou quem está com que pele. O "animal" implica um reconhecimento de uma humanidade que passa pelo olhar e que está ausente na caça. ${ }^{40}$

No que se refere aos rios amazônicos, populações negras do rio Trombetas têm um personagem que entrelaça esses mundos que é o Sacaca. Esse feiticeiro tem a capacidade de levantar a beira do rio e passar por baixo dele sem se molhar. Podendo inclusive ficar pelo período que queira abaixo do rio (mas fora da água). Eliane Cantarino O’Dwyer (2005, p. 101-102) descreve assim dois famosos Sacaca de Oruximilá:

[Balduino] Tinha também o dom da onipresença, sendo visto por eles e até pelas suas crianças nos locais mais distantes: dentro das matas, no fundo dos rios, sentando em cima de uma sucuriju, como se fora um trono onde passava dias sem aparecer na superfície. [...] Chico Melo contou a sua mulher que foi levado ao fundo do rio, para conhecer um hospital no qual os peixes o ensinaram a prescrever remédios, sem a ajuda dos doutores brancos da cidade. Dizia para a mulher: "Maria, o outro mundo é muito bonito. Só que a gente não pode ficar lá, só se criar guelra".

Observo que O’Dwyer (2005) descreve a atuação do Sacaca entre os quilombolas do Trombetas, mas o próprio nome e a maneira como o Sacaca atravessa níveis é americana (tupi). Vários grupos indígenas sul e norte americanos têm em comum essa representação do universo em camadas. E em que o Xamã passa de uma a outra sem alterarse. Eduardo Galvão afirma que o universo do pajé Sacaca é caboclo (O’DWYER, 2005). Asdiwall vai à casa das focas dentro dum rochedo abaixo do mar e lá convive com elas (LEVI-STRAUSS, 1976). Também a casa do cumpadre é reportada como dentro do barranco, abaixo da água e que lá não é molhado.

\section{Para Terminar: os barcos, as afirmações e as perguntas finais}

Finalmente, para completar a descrição desses poros entre cosmologias e políticas, é importante falar de alguns objetos feitos, em particular, os barcos. Esses também são pensados dentro desse 
entrelaçamento de vidas. Não me parece que posso, com o relato que apresentarei abaixo chegar a mesma conclusão acerca do fetichismo a que chega Goldman (2009), de que a feitura lapida, faz emergir algo que estava latente no objeto ou pessoa, numa metáfora da escultura a partir da retirada (embora Goldman fale sobre esculturas em madeira, trata-se da ideia de que Miguelangelo libertava de dentro do bloco de mármore o cavalo que estava preso ali), pois parece que a feitura é diferente se é com cinzel e martelo ou fogo e martelo, pois neste último caso é o caráter plástico e maleável, que se evidencia, como nos ritos de passagem em que uma pessoa é colocada em outra forma (STRATHERN, 1997). Todavia é importante salientar o caráter do fetiche como "coisa feita". No caso dos barcos há uma série de paralelos, metáforas e metonímias que, num primeiro momento ajudariam um pensamento desencantado a pensar a posição destes dentro do sistema "meramente alegórico": barcos a vapor "comem" lenha, mas também transportam pessoas em seu "ventre".

Só que novamente as narrativas são um pouco mais radicais.

Assim, como eles são do rio, os barcos como eles também têm sentimentos. Vale falar de um naufrágio ocorrido perto de Matias Cardoso-MG:

Pior de tudo foi um vapor, o Fernandes da Cunha, que queimou comigo lá dentro. Eu era camareira, só saí com a roupa do corpo que nem estou aqui e o sapato do pé. Mas o que foi de roupa, de tudo, de jóia: prata branca, sapato branco. Queimou que virou cinza.

Não teve acidente de morte que, quando conheceu que o vapor tava pegando fogo, o comandante gritou e o pessoal da segunda alvoroçou. o prático puxou pra praia, pra beira do barranco. Puxou o vapor chega bateu a proa do vapor. Mas quando bateu lá, essa parte de cima que tinha o meu camarote já tava caindo tudo lá. Era pintado de tinta, a tinta pegou fogo, mas os trens que nós trouxemos, pé de planta, pé de coco, só vendo o fogo...

Mas queimou total, só ficou o caixão baixo. Aí já um bocado, tirou um bocado de trem, mas também perdeu um bocado. Perdeu tudo, total.

Na derradeira, como é que chamava, esse vapor tirou cada gemido: feito criatura.

Embarcação geme. O povo me dizia isso e eu não acreditava. Embarcação quando está se naufragando ele tira os três gemidos: o vapor tirou assim aquele gemido tão profundo que balançou a terra. Não teve quem não 
chorasse. Mas o gemido aí... taí o contramestre que também viu. O Comandante era Nelson Gualberto. Aí o outro falou com ele 'Ô comandante, eu ouvia dizer que embarcação chorava, mas nunca acreditei mas to vendo agora. Mas tirou aquele gemido profundo UOOO. Assim de chega foi, foi acabando acabando acabando. Então quando tomava [fôlego para gemer?]: três vezes, até a última.

Que acabou tudo, que desceu o derradeiro pedaço de, de... Até hoje nunca saiu de minha memória. (Dona Joana, 65 anos - Pirapora)

Mas então, como ficamos? O rio não tem vontade? Não fala? Como não aceitar isso? Como uma vez escreveu Guimarães Rosa, “cada um com seu cada qual". Termino este texto - em que tentei organizar uma série de narrativas recolhidas bastante difíceis de classificar no entremeio do sertão, com os possíveis encontros (muitas vezes dramáticos) que os geraram - com o acontecimento mais mágico que presenciei durante minha pesquisa de campo. Transcrevo de minha caderneta:

Ainda no porto de Januária, estávamos, eu, Juvenal e Rivelino, sentados na amurada da barca Sinhá Licinha quando veio e passou por nós uma pipa, bruxuleando a uns cinco metros da água. Um menino a havia perdido e agora ela flutuava, empinada pelo rio e assim continuou, até sumir no horizonte. Não caiu n'água, como alguns na barca achavam que ia acontecer, pois o rio que corria em direção oposta ao vento faziase menino. Ou talvez fosse o Cumpadre d'água ou o Romãozinho que estivesse ali brincando. (Porto de Januária, bordo da barca Sinhá Licinha)

Durante a mais de meia hora em que isso durou, de nada mais se falou, e o assunto ficou voltando de vez em quando, como essa imagem me volta aos olhos agora.

\section{Agradecimentos}

Agradeço à Capes pela bolsa de pós-doutorado no exterior que me permitiu tirar do arquivo morto vários textos que estavam esperando serem completados, assim como agradeço às instituições que me apoiaram na pesquisa, o Colégio do México e o Ciesas. Este artigo levou muito tempo entre começar a ser escrito e ser aceito para publicação, portanto, queria agradecer a algumas pessoas que aportaram ideias aqui, em particular Alexandre Herbetta, Suely Koffes, Simone Frangella 
e os três pareceristas anônimos da Revista Ilha. As imprecisões, claro, são minhas.

\section{Notas}

1 Para uma discussão das diversas imagens do rio São Francisco no discurso nacional e os nomes que lhe foram dados em cada uma, sugere-se a leitura de Vanessa Brasil (1999).

2 Embora não fique claro neste artigo em questão, em outros lugares Lévi-Strauss explica que as diferenças entre contos e mitos devem ser buscadas na grandeza das oposições que cada um pretende solucionar (maiores nos mitos), assim como o lugar do conteúdo do narrado em relação à explicação que a referida população dá ao mundo.

3 Não é uma crítica a Lévi-Strauss, também não é pretensão aqui fazer uma exegese de seu pensamento, a ideia é, pela via torta, pensar alguns temas contidos em seus primeiros textos sobre análise mítica através da diáspora e do colonialismo ( tanto o clássico quanto o interno), assim como pensá-lo por meio das propostas de releituras de Eduardo Viveiros de Castro (2002; 2008) e Marcio Goldman (2009). Levar ao sertão essas reflexões. Isso porque, existem algumas contradições básicas presentes nas narrativas que se seguem, como terra/água, homem/peixe, homem/ animal/caça e (quem sabe) humano/natureza que fazem eco aos famosos textos da "a gesta de Asdiwal" e outros subsequentes, como o "pensamento selvagem" (1997), e fazem lembrar a aposta metodológica contida nesses escritos, de que a análise deve estar firmemente ancorada na etnografia e no meio físico em que essas relações são retratadas e narradas.

4 Concordamos com Anibal Quijano (2005), quando ele considera que a raça no sentido moderno ocidental é a primeira categoria a dividir toda a humanidade, e que o racismo é o centro do colonialismo, esse último, coetâneo e quase sinônimo de modernidade. Lembrando ainda que para Quijano a modernidade/colonialidade nasce da expulsão dos árabes da península ibérica, da invasão e massacre nas Américas e do tráfico negreiro atlântico.

5 Pescador aposentado, 74 anos à época da entrevista ("aposentados" refere-se aqui a uma classificação previdenciária: quase todos esses pescadores que aqui estarão presentes com suas narrativas ainda pescavam quando os entrevistei)

6 “Calderón mantuvo la orden de generar la menor energía posible, para que las empresas privadas que se dedican ilegalmente a la misma tarea produjeran más, se la vendieran al propio "gobierno" y de tal modo incrementaran sus ganancias particulares" (La Jornada, 17/1 1/2007, grifos no original)

7 É certo que para a água, nenhuma fronteira é natural. São todas elas frutos de alguma relação política mediadas por aquela.

8 Exceptuando os rios citados por Levi-Strauss, que seguem para o Pacífico, os rios até agora citados neste artigo (Grijalba, Pilcomayo e São Francisco) são rios que caminham eternamente para o Atlântico. Não tenho conhecimento da importância do Skeena e do Nass para o imaginário da nação Canadense, mas seguramente os outros três rios importam para o pensamento social nacional de México Paraguai e Argentina e Brasil. As diferenças dos relatos no material que disponho me levam também em direção a diferenças (e semelhanças) de projetos nacionais. 
9 Esse tema recorrente está ligado a uma pratica ribeirinha posta em ação quando da impossibilidade de realizar uma prometida romaria a Bom Jesus da Lapa. Os moradores das cidades rio acima colocavam suas orações e agradecimentos em cabaças e as deitavam no rio, pois este se encarregaria de entregá-las na Lapa de Bom Jesus. Inclusive se um pescador vir uma destas mensagens presa a uma das margens, tem a obrigação moral de colocá-lo de volta no meio do rio.

${ }^{10}$ Composta por Jerome Kern e letrada por Oscar Hammerstein II em 1927 para o espetáculo showboat, a letra original da melodia tratava de relações de dominação por meio de termos pejorativos. Robeson, como ativista negro, modificou-a para dar um caráter insurgente. Eis a poesia original: Niggers all work on the Mississippi, Niggers all work while the white folks play. I gits weary and sick of tryin'; I'm tired of livin' and scared of dyin', And $\mathrm{Ol}^{\prime}$ man river, he just keeps rollin' along. Disponível em: http://www.rutgers.edu/robeson/oldman.html. Acesso em: 22 jun. 2001.

${ }^{11}$ Em um segundo sentido, como lugar de resistência, sem dúvida há aproximação entre as margens e caudais dos quatro rios atlânticos citados até agora.

12 Em outro texto, Benjamin (1971, p. 167) trata da mesma questão da seguinte forma: "El don de percibir semejanzas, que [el hombre moderno] posee, no es más que el resto rudimentario de la obligación en un tiempo violenta de asimilarse y de conducirse de conformidad con ello".

13 Tantas vezes interpretada como irracionalista.Ver por exemplo Lefort (1979), que acusa Mauss de ter sido embruxado pelos Maori, criando uma "teoria da mistura universal".

14 Estou ciente de que estou torcendo o que quis dizer Mello Neto, pois ele escrevia sobre os rios intermitentes de Pernambuco, mas a experiência dos povos ribeirinhos que passaram pelo trauma de ter uma represa em seu rio está bem representada na poesia.

15 Um bom trabalho sobre os saberes dos pescadores artesanais são-franciscanos e a análise campanha de descrédito a eles endereçada pelas elites está na tese de Ana Thé (2003).

16 Sobre o rio dormir, obtive relatos em todas cidades em que passei. Quanto ao trabalho do rio na corredeira, tive algumas alusões, mas nenhuma exegese que me permita aprofundar o tema.

17 Pescador aposentado, 70 anos à época da entrevista.

18 Pescador aposentado, 92 anos à época da entrevista.

19 No caso específico, principalmente entre gente-gente e gente-peixe como também é discutido por Aluísio Cabalzar (2005) na Amazônia.

20 Sangradouros são também pontos importantes de referência. Para o caso de uma retomada de terras que passa pela relação com os sangradouros em uma cidade São Franciscana, ver Izadora Acipreste (2015).

21 "O autêntico animista é o antropólogo, e a observação participante é a verdadeira (ou seja, falsa) participação primitiva". (VIVEIROS DE CASTRO, 2002, p. 117)

22 "[...] o mundo, [nza] torna-se uma realidade física flutuando no kalûnga (na água sem fim dentro do espaço cósmico); meio emersa para a vida terrestre e meio submersa para a vida marinha e o mundo espiritual. O kalûnga, também significando oceano, é uma porta e uma parede entre esses dois mundos" (FU-KIAU, 2001, p. 20, tradução livre minha)

${ }^{23}$ A casa do cumpadre é abaixo do rio, mas não é dentro da água. 
24 Não estou dizendo que outras relações de parentesco não existam/não importem, ou que na prática muitas coisas podem acontecer, estou indicando apenas a importância do parentesco ritual na cosmologia "cristã", dos cunhados nas sociedades "da aliança" e do tio como operador do parentesco nas sociedades "segmentares", com os riscos que tal tipologia pode levar. Vou retornar a isso adiante, em particular na discussão que faço de uma afirmação do pescador, de Januária, Manu Guia frente a um conto de Guimarães Rosa.

${ }^{25}$ Pescadores aposentados. Zé de Lió tinha 74 anos na época da entrevista.

${ }^{26}$ A faca não é para ser usada diretamente contra ele, ninguém se atreveria, pois isso significaria ao pescador que ele nunca mais poderia chegar perto do rio, mas a faca, se espetada no fundo do barco, espanta-o, como no seguinte relato colhido em Pirapora:

“Eu, Magela, que outro aí meu deus do céu, se eu alembro quem era o outro... Andani de Andradina! Agora eu não sei se foi era 'superstição de gole meu', que nós já tinha bebido, mas não foi isso, gole não. Você sabe onde é o porto de Alexandre, né? Por baixo da Tocaia, pelo lado de cá. Vocês podem acreditar como existe Deus no céu: Se solto, era uma hora dessa, era que o rio tava alto, nós por cima do Tocaia, naquele pau caído que é o lanço de rede, nós batemos remo, batemos remo, batemos remo... uma hora dessas, tipo se fosse mais tarde era pouca coisa, a gente vendo. E um radinho ligado na lancha [da colônia] e, nós escutava o pessoal todo conversando na lancha, que você sabe que a água é um eco do caramba, e nós batia remo e nada desse barco andar... e aquele negócio. Aí eu fui e falei com Magela, 'ô meu Deus', a gente estava em três, falei: 'Magela, você está desconfiando de alguma coisa?'

[ele respondeu:] 'É Tiriri, você também desconfiou'. Aí ele foi debaixo da proa do barco, e isso aí a finada minha mãe já tinha falado mesmo, e enfincou a faca no meio do barco e o barco começou a andar.

Eu acho que era ele, que diz que quando ele segurar num barco, num negócio de brincadeira, não vai para lugar nenhum. Minha mãe já tinha contado isso e Magela também estava por dentro: pegou, enfiou a faca no meio do barco e o barco começou a andar $[\ldots]$.

Ele pega o barco e segura mesmo, brincando com a gente, né, que se quisesse tombar ele tombava mesmo e fodia com a gente mesmo, mas é uma brincadeira sem graça, que a gente fazendo força e ele ali segurando [risos- alguém ouvindo comenta: "moleque a toa, né"]. Menino, eu cheguei na barca arrepiadinho. [...] Também foi só essa vez." (Tiriri, pescador, cerca de 50 anos à época da entrevista, Pirapora).

${ }^{27}$ Como já escrevi, os pescadores acima de 80 anos que entrevistei tinham o costume de ter entre as mãos um pedaço de fumo quando iam pescar, para dar ao cumpadre

${ }^{28}$ Aliás, se estas não definem as relações de compadrio, parentesco espiritual mediado por filhos e afilhados, são marcas das relações cotidianas entre os cumpadres. Ver, por exemplo, Emília Godói (1999).

29 Consiste em amarrar uma corda curta, pouco menor que a profundidade do rio, a uma cabaça, iscá-la com uma isca viva, soltar a cabaça descendo o rio e ir acompanhando. Quando um peixe morde o anzol, a cabaça fica balançando como o brinquedo de criança.

30 Assim como na teoria do sacrifício, o sacrificado é um subterfúgio para entrar em contato com o insondável, a vida sob as águas é alcançada com anzóis e redes. Causa espanto e mesmo indignação em muitas cidades ribeirinhas saber de pessoas que mergulham e arpoam peixes sob a superfície. Conversando com um pescador durante o descanso entre uma e outra jogada de rede ele explicava sobre o mergulho: 
“que ele [referindo-se ao companheiro que dirigia a barca] não mergulha, e aí ele precisa de mim que mergulha. Para soltar a rede quando ela prende embaixo d'água. A gente mergulha e não vê nada, então a gente vai seguindo a rede, apanhando ela fechada na mão e não sabe se tem piranha que vai arrancar a mão da gente. E a água estoura nossos olhos e ouvidos: a gente sempre sobe com sangue saindo dos olhos, nariz e ouvidos. Não é todo mundo que tem coragem". No total desconhecimento de manobras de descompressão, aliado ao perigo inerente de prender-se no matagal submerso e dos peixes agarrados a rede, a narrativa tem muito de uma experiência iniciatória neste orum ou mundo dos encantados aquático.

${ }^{31}$ Uma variante deste ditado é "o tanto de cabelo que tem em cima d'água, tem embaixo", embora aqui não fique clara a distinção entre dentro e por sob.

32 Retornarei adiante a esse tema, mas deve ficar marcada a diferença entre a paridade e o duplo. E que às vezes é o primeiro conceito que aparece e em outros momentos é o segundo.

33 Claramente aqui é o ambíguo ou o impar a que se chama a atenção. Um artigo muito interessante é o já citado de Slennes, "a grande greve do macuxi" em que o autor analisa um motim em que escravos africanos se negam a embarcar um esqueleto de macuxi na costa do Rio de Janeiro, cuja forma do crânio lembrava de perto um crânio humano com um bico. Esse é um caso diferente da comunicação transespecífica central para o perspectivismo ameríndio.

34 Guimarães Rosa, filólogo e conhecedor de duas dúzias de línguas nos oferece diversas pistas de que ele também via essas encruzilhadas a que me refiro. Como no nome do herói de Grande Sertão: veredas, que advém do latim (Rio: curso de água), do árabe (baldo: inútil, vão) e do tupi (tatarana: semelhante a fogo).

35 Sobre a onça como animal totêmico: “Os estudiosos já apontaram a notável onipresença dessa onça mítica pelas Américas, entre povos de origens diferentes, e pertencentes a grupos linguísticos diferentes. O culto do chamado 'jaguar solar' aponta para a dimensão mais que brasileira, também americana, do conto. Conhecemse, em alguns lugares mais, em outros menos, evidência desse culto em toda parte, desde um pouco ao norte do México até o extremo sul do continente". (WALNICE GALVÃO, 2008, p. 12 apud NOGUEIRA, 2013, nota 3).

36 É curioso que no Brasil "branco" as pessoas se refiram a esse animal pelo latino "onça" e na mesoamérica "branca" seja referido como "jaguar" (e não pelo maia "balam", por exemplo).

37 Perrone (2008) chama a atenção que apenas em 2000 um leitor (Gorgozinho Filho) questionou se o narrador morre ou não no final do conto: se sobrevive ao ataque do visitante como pessoa ou como jaguar.

38 Para variar, Rosa deixa o leitor na dúvida: ele descreve o narrador (enquanto humano) como filho de um homem branco e uma mulher índia, mas a experiência de ocultamento que é descrita na vida do narrador tanto pode remeter a experiência de desaldeamento, como também às narrativas de quilombolas - ver Barlet (1966). Aliás, um dos nomes que teve o ex-caçador de onça foi um nome africano "macuncôzo" - ver Nogueira (2013, nota 8).

39 Estas passagens/transformações também estão na famosa entrevista/desafio de Rosa com Lorenz: “Quando escrevo, repito o que já vivi antes. E para estas duas vidas, um léxico só não é suficiente. Em outras palavras, gostaria de ser um crocodilo vivendo no rio São Francisco. O crocodilo vem ao mundo como um magister da metafísica, pois para ele cada rio é um oceano, um mar de sabedoria. [...] Gostaria de ser um crocodilo porque amo os grandes rios, pois são profundos como a alma de 
um homem. Na superfície são muito vivazes e claros, mas nas profundezas são tranqüilos e escuros como o sofrimento dos homens. Amo ainda mais uma coisa de nossos grandes rios: sua eternidade. Sim, rio é uma palavra mágica para conjugar eternidade" (LORENZ, 1994, p. 37)

${ }^{40}$ Repare a diferença do olhar na narrativa de Zé de Lió, que perde o controle do corpo ao ser olhado pelo cumpadre com a descrição dos olhos de Maria-maria e a troca de olhares entre ela e o narrador de Meu tio o Iauareté: "Vi aqueles olhos bonitos, olho amarelo, com as pintinhas pretas bubuiando bom, adonde aquela luz... Aí eu fingi que tava morto, podia fazer nada não. Ela me cheirou, cheira-cheirando, pata suspendida, pensei que tava percurando meu pescoço. Urucuera piou, sapo tava, tava, bichos do mato, aí eu escutando, toda a vida... Mexi não. Era um lugar fofo prazível, eu deitado no alecrinzinho. Fogo tinha apagado, mas ainda quentava calor de borralho. Ela chega esfregou em mim, tava me olhando. Olhos dela encostavam um no outro, os olhos lumiavam - pingo, pingo: olho brabo, pontudo, fincado, bota na gente, quer munguitar: tira mais não. Muito tempo ela não fazia nada também. Depois botou mãozona em riba de meu peito, com muita firmeza. Pensei - agora eu tava morto: porque ela viu que meu coração tava ali. Mas ela só calcava de leve, com uma mão, afofado com a outra, de sossoca, queria me acordar. Eh, Eh, eu fiquei sabendo... Onça, que era onça - que ela gostava de mim... Abri os olhos, encarei. Falei baixinho: - "Ei, Maria-Maria... Carece de caçar juízo, Maria-Maria..." Eh, ela rosneou e gostou, tornou a se esfregar em mim, mião-miã. Eh, ela falava comigo, jaguanhénhém, jaguanhém..."

\section{Referências}

ACYPRESTE, Izadora Pereira. Se movendo por território: os caminhos traçados pela comunidade de Sangradouro Grande para a garantia do território. 2015. Dissertação (Mestrado) - Universidade Federal de Goiás, Goiânia, 2015.

ARANTES, Antonio Augusto. Pais, padrinhos e o Espírito Santo: um reestudo do compadrio. In: ARANTES, A. A. et al. Colcha de retalhos: estudos sobre a família no Brasil. 2. ed. Campinas: UNICAMP, 1993. p. 195-204.

ASHCROFT, Bill; GRIFFITHS, Gareth; TIFFIN, Hellen. Key concepts in post-colonial studies. London; New York: Routledge, 1998.

BARNET, Miguel. Biografía de un cimarrón. La Habana. Instituto de Etnología y Folklore, 1966.

BENJAMIN, Walter. On the Philosophy of History. In: BENJAMIN, Walter. Illuminations. Tradução de H. Zohn. New York: Schocken Books, 1968. p. 253-264.

BENJAMIN, Walter. Magia e técnica, arte e política. Tradução de Sergio Rouanet. São Paulo: Brasiliense, 1985.

BHABHA, Homi. O Local da Cultura. Belo Horizonte: UFMG, 1998. 
BRANDÃO, Carlos Rodrigues. O Desencanto do Outro: Anuário Antropológico 91. Rio de Janeiro: Tempo Brasileiro, 1993.

BRASIL, Vanessa. Margens e Veredas do São Francisco: as Vozes do Rio. 1999. Tese (Doutorado) - Programa de Pós-Graduação em História da Universidade Federal do Rio de Janeiro, Rio de Janeiro, 1999.

CABAlZAR, Aloisio. Peixe e Gente no Alto Rio Tiquié. Rio de Janeiro: ISA, 2005.

CLIFFORD, James. Dilemas de la Cultura: Antropología, literatura y arte en la perspectiva posmoderna. Barcelona: Gedisa, 1998.

CULLER, Jonathan. Sobre a Desconstrução. Rio de Janeiro: Rosa dos Tempos, 1997.

EVANS-PRITCHARD, Edward E. Os Nuer. São Paulo: Perspectiva, 1978

FAVRET-SAADA, Jeanne. Ser afetado. Cadernos de Campo, [S.l.], v. 13, 2005.

FOUCAULT, Michel. Vigiar e Punir. Petrópolis: Vozes, 1989.

GALVÃO, Eduardo. The religion of an Amazon community: a study in culture change. 1952. Tesis (Doctor of Philosophy) - Columbia University, Columbia, 1952.

GEERTZ, Clifford. A Interpretação das Culturas. Rio de Janeiro: Guanabara, 1989.

GODOI, Emília. O Trabalho da Memória. Campinas: UNICAMP, 1999.

GOLDMAN, Marcio. Histórias, devires e fetiches das religiões afrobrasileiras: ensaio de simetrização antropológica. Análise Social, [S.l.], v. XLIV, n. 190, p. 105-137, 2009.

GORDILLO, Gastón. Canales para un rio indómito. Frontera, Estado y utopías aborígenes en el noroeste de Formosa. In: GRIMSON, Alejandro. Fronteras, naciones e identidades. Buenos Aires: Ciccus, 2000. p. 232-255.

LEFORT, C. A troca e a luta dos homens. In: LEFORT, C. As Formas da História. São Paulo, Brasiliense, 1979. p. 21-35.

LÉVI-STRAUSS, Claude. A Gesta de Asdiwal. In: LÉVI-STRAUSS, Claude. Antropologia Estrutural dois. Rio de Janeiro: Tempo Brasileiro, 1976. p. 152-206.

LÉVI-STRAUSS, Claude. A Eficácia Simbólica. In: LÉVI-STRAUSS, Claude. Antropologia Estrutural. Rio de Janeiro: Tempo Brasileiro, 1989. p. 215-236.

LÉVI-STRAUSS, Claude. História de Lince. Barcelona: Anagrama, 1992. 
LÉVI-STRAUSS, Claude. El pensamiento salvaje. México: Fondo de Cultura Económica, 1977.

LIMA, Roberto. Um rio São Muitos. 2002. Tese (Doutorado) - PPGAS da Universidade de Brasília, Brasília, 2002.

LORENZ, Günther. Diálogo com Guimarães Rosa. In: ROSA, João Guimarães. Ficção completa. Rio de Janeiro: Nova Aguilar, 1994. 2 v. p. 27-62.

MAUSS, Marcel. Sociologia e antropologia. São Paulo: EPU/Edusp, 1974. v. II.

MELLO NETO, João Cabral. Antologia poética. 5. ed. Rio de Janeiro: José Olympio, 1979.

NOGUEIRA, Erich Soares. A voz indígena em "Meu tio o iauaretê", de Guimarães Rosa. Nau Literária, [S.l.], v. 9, n. 1, 2013.

O'DWYER, Eliane Cantarino. Os quilombos e as fronteiras da antropologia. Antropolítica, [S.l.], n. 19, p. 91-111, 2005.

PERRONE, Charles A. Notas para facilitar a leitura de "Meu tio o iauaretê". Hispania, [S.l.], v. 91, n. 4, 2008.

QUIJANO, Aníbal. Don Quixote e os moinhos de vento na América Latina. Estudos Avançados, [S.l.], v. 19, n. 55, 2005.

ROSA, João Guimarães. Ficção completa. Rio de Janeiro: Nova Aguilar, 1994. $2 \mathrm{~V}$.

ROSA, João Guimarães. Magma. Rio de Janeiro: Nova Fronteira, 1977.

SÁ, Maria Auxiliadora Ferraz. Dos Velhos aos Novos Coronéis. Recife: PIMES, 1974.

SAHLINS, Marshall. Cosmologias do Capitalismo: o setor trans-pacífico do 'sistema mundial'. In: XVI REUNIÃO BRASILEIRA DE ANTROPOLOGIA (ABA). Campinas, 1988. Anais [...], Campinas, IFCH, 1988.

SAID, Edward. Orientalismo. São Paulo: Companhia das Letras, 1990.

SAID, Edward. Representar al colonizado. In: STEPHAN, B. G. (org.).

Cultura e tercer mundo. Caracas: Nueva Sociedad, 1996. p. 23-59.

SLENES, Robert W. A grande greve do crânio do Tucuxi: espíritos das águas centro-africanas e identidade escrava no início do século XIX no Rio de Janeiro. In: HEYWOOD, Linda M. (org.) Diáspora negra no Brasil. São Paulo: Contexto, 2008. p. 193-217.

STRATHERN, Marilyn. Entre uma melanesianista e uma feminista.

Cadernos Pagu, [S.l.], v. 8/9, p. 7-49, 1997. 
TAUSSIG, Michael. Mimesis and alterity. New York; London: Routledge, $1993 a$.

TAUSSIG, Michael. Xamanismo, colonialismo e o homem selvagem. Rio de Janeiro: Paz e Terra, 1993b.

THÉ, Ana Paula Glinfskoi. Conhecimento ecológico, regras de uso e manejo local dos recursos naturais na pesca do alto-médio São Francisco, MG. 2004. Tese (Doutorado) - Universidade Federal de São Carlos, São Carlos, 2004.

VIVEIROS DE CASTRO, Eduardo. O nativo relativo. Mana, [S.l.], v. 8, n. 1, 2002.

VIVEIROS DE CASTRO, Eduardo. Xamanismo transversal: Lévi-Strauss e a cosmopolítica amazônica. In: QUEIROZ, Ruben Caixeta de; NOBRE, Renarde Freire. (org.). Lévi-Strauss: leituras brasileiras. Belo Horizonte: Editora UFMG, 2008. p. 79-124.

WOORTMANN, Klaas. Cosmologia e Geomancia: um estudo da cultura Yorùbá-Nágô. Anuário Antropológico 77, [S.l.], 1987.

Recebido em: 05/08/2017

Aceito em: 23/03/2020

\section{Roberto Lima}

Doutor em antropologia pela Universidade de Brasília, professor na Universidade Federal de Sergipe e pesquisa temas relativos a populações ribeirinhas no Brasil e no México.

Endereço profissional: Departamento de Ciências Sociais, Universidade Federal de Sergipe, Cidade Univ. Prof. José Aloísio de Campos, Av. Marechal Rondon, s/n, Jd. Rosa Elze, São Cristóvão, SE. CEP: 49100-000.

E-mail:nadanacuca@gmail.com 